\title{
Physical and chemical characteristics of soybean preserve as a function of maceration time and acetic acid
}

\author{
Adriana Luiza Wain TASSI ${ }^{1}$, Juliana Aparecida Correia BENTO${ }^{1}$, Márcio CALIARI ${ }^{1 \star}$, Vera Sônia Nunes da SILVA², \\ Maria Teresa Bertoldo PACHECO², Manoel Soares SOARES JÚNIOR ${ }^{1}$
}

\begin{abstract}
Food-type soybean, considered a functional and nutritious food, becomes an new alternative food in human nutrition, and its preserve is an option to the consumer market. The present study aims to verify the effect of maceration time of the grains and the acetic acid concentration in brine on the physical and chemical characteristics of a edible soybean preserves, and to evaluate the proximal composition, microbiological risk and sensory acceptance of the selected preserve. The methodology used was the response surface and the central composite rotational design. The presence of acetic acid in the brine was prejudicial to the quality of the edible soybean preserve - BRSMG 790A cultivar. The soybean preserve with the best characteristics was obtained with a maceration time of 100 minutes and without the addition of acetic acid. The product was microbiological safe, showed

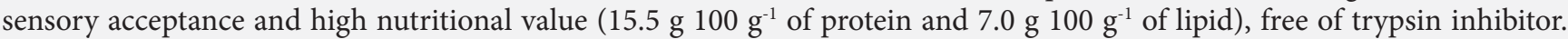
The essential amino acids represented $17.2 \%$ of those in the dry grain, more than $50 \%$ the standard values proposed for the essential amino acids for children and adults. The selected preserve maintained $31.25 \%$ of the antioxidant activity of the grains and could be used as a viable technological option.
\end{abstract}

Keywords: Glycine $\max (\mathrm{L}$.$) Merrill; texture; total phenolic; antioxidant activity; amino acids; trypsin inhibitor.$

Practical Application: The food industries have been looking for new food products, which provide in addition to nutritional function for consumers, functional value. The soybean preserve is an interesting product that present antioxidant activity and phenolic compounds. Besides that, soybean preserve it's a way to improve the acceptance of the soybean by the consumers.

\section{Introduction}

The search for healthy, functional foods has contributed to an increase in research for the development of soybean products (Glycine max (L.) Merril), since the consumption of this legume provides benefits to consumer health (Sanjukta \& Rai, 2016). The BRSMG 790A is a special cultivar developed for human consumption, mainly due to its high protein content.

The process applied influences the final quality of several products developed with this legume. Thus a study of the processing parameters of the edible soybean preserve is justified, since the processing variables must be controlled with a view to maximizing the quality parameters of the vegetable preserve, such as color, flavor and texture.

The time of maceration or hydration of the grains, carried out before blanching and thermal treatments, are conditions essential to the process of obtaining the preserve (Boz \& Erdogdu, 2015). Maceration may contribute to the reduction of some anti-nutritional compounds, such as tannins. The action of enzymes lipoxygenases when soybean grains are soaking in water is responsible for the undesirable taste of soybean. The origin of this undesirable taste is in the oxidation of fatty acids, catalyzed by lipoxygenase isoenzymes, when grain tissues are damaged in the presence of moisture. During maceration of the grains, the cotyledon cells suffer ruptures due to the swelling caused by the rapid absorption of water, allowing for enzyme-substrate contact (Khattab \& Arntfield, 2009).

On the other hand, the components of the brine used in obtaining the preserve, such as sodium chloride, acid, sucrose and others, can also affect the quality aspects, such as a loss of solids, and the texture, color and sensory acceptance (Czaikoski et al., 2013). Acetic acid, produced by fermentation with the bacterium acetobacter, is a potential product for application in preserves, showing acidifying and conservation properties. Moreover, the compounds derived from acetic acid function as sequestering and flavoring agents (NIIR Board of Consultants \& Engineers, 2016). The present study aims to verify the effect of maceration time of the grains and the acetic acid concentration in brine on the physical and chemical characteristics of a edible soybean preserves, and to evaluate the proximal composition, microbiological risk and sensory acceptance of the selected preserve. 


\section{Materials and methods}

\subsection{Raw materials}

The yellow tegument soybean (BRSMG-790A cultivar) used to prepare the preserves was cultivated in a conventional system on Campus II of the Federal University of Goiás, Goiania - GO, Brazil, during the 2013/2014 season. The seeds were donated by the company Epamig (Empresa de Pesquisa Agropecuária de Minas Gerais). After cultivation, the grains were harvested and selected manually. The P.A. acetic acid (Sigma $\left.{ }^{\circledR}\right)$, fresh garlic and virgin olive oil $\left(\mathrm{Galo}^{\circledR}\right)$ were purchased from local shops in Goiania.

\subsection{Processing of the soybean preserves}

A Central Composite Rotational Design was used totaling eleven experiments (Box et al., 2005). The independent variables were the acetic acid concentration in the brine (relative to the mass

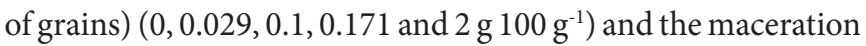
time $(0,13.6,50,85.4$ and $100 \mathrm{~min})$. The selected grains were macerated in mineral water for the different times as defined by the experimental design followed by blanched in boiling water for 5 min using a 1:5 ratio, immediately drained and washed in cold water for approximately $1 \mathrm{~min}$. After these unitary operations, the preserves were processed using approximately 35 grains per unit, packed in $30 \mathrm{~mL}$ transparent recipients containing $1 \mathrm{~g}$ of garlic (chopped and fried in virgin olive oil) and a covering liquid (approximately $15 \mathrm{~mL}$ ) composed of mineral water and

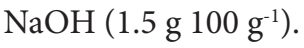

Exhaustion was carried out for $10 \mathrm{~min}$, followed by the addition of different concentrations of acetic acid as defined by the experimental design. The recipients were immediately sealed, placed in the pre-heated autoclave and heat treated for $15 \mathrm{~min}$ at $120^{\circ} \mathrm{C}$, followed by the gradual addition of cold water into the open autoclave to cool the products. The final products were stored at a refrigeration temperature of $5^{\circ} \mathrm{C}$ until analyzed.

All the experimental soybean preserves were analyzed for the solids losses to brine during processing, instrumental hardness, total phenolic compounds and the moisture content of the preserved grains. The chemical composition, total amino acid profile and the level of trypsin inhibitor in the preserved grains were only determined in the selected preserve. The preserve with higher total phenolic compound values and lower instrumental hardness values and solids losses was considered to be the most desirable. All analyses were carried out in triplicate, except for the total amino acid profile, which was carried out in duplicate. The microbiological risk and sensory acceptance were also evaluated.

\subsection{Instrumental hardness}

Six whole grains were analyzed per experiment using a texturometer (TA, XT2, Halesmere, England) equipped with a20 mm diameter aluminum cylindrical probe (P20). The pre-test, test and post-test speeds were set at $2 \mathrm{~mm} \mathrm{~s}^{-1}$, with a height of $15 \mathrm{~mm}$.

\subsection{Bioactive compounds and antioxidant activity}

Extracts were obtained for the quantification of the total phenolic compounds and antioxidant activity according to the method reported by Hung et al. (2009). The total phenolic compounds were quantified according to the method proposed by Singleton et al. (1999), determining the absorbance at $760 \mathrm{~nm}$ in a spectrophotometer (BEL Photonics, S 2000 UV, Osasco, Brazil). The results were expressed as mg gallic acid equivalents per gram of sample (mg GAE g ${ }^{-1}$ ) on a dry weight basis. The total condensed tannins content was estimated colorimetrically according to the methods of Price et al. (1978). The antioxidant activity was determined by the 2.2-diphenyl-1-picryl-hidrazil (DPPH) radical-scavenging method, according to Thaipong et al. (2006), measuring the absorbance at $517 \mathrm{~nm}$ using a spectrophotometer (BEL photonics, S 2000 UV, Osasco, Brazil). The total antioxidant activity was expressed as s a percentage of the absorbance of the control DPPH solution.

\subsection{Solids loss}

The solids losses of soybean to the brine of preserves (g) were determined by evaporating $5 \mathrm{~mL}$ of water in an oven (Tecnal, $394 / 3$, Piracicaba, Brazil) at $105^{\circ} \mathrm{C}$ to constant weight, and then calculating for the total volume of liquid.

\subsection{Proximal composition}

The chemical composition was determined according to the methods recommended by the Association of Official Analytical Chemists (2012). The moisture content was determined in an oven at $105^{\circ} \mathrm{C}$ (method 925.45b). Total nitrogen was quantified by the micro-Kjeldahl method in a nitrogen distiller, and the protein content estimated by multiplying the total nitrogen by 6.25 (method 960.52). The lipid content was determined in a Soxhlet apparatus (Tecnal, TE-044, Piracicaba, Brazil) using petroleum ether P.A. (method 920.39). The ash content was determined by incineration in a muffle furnace (EDG, Oven Economic, São Carlos, Brazil) (method 923.03) and the carbohydrate content estimated by difference. All values

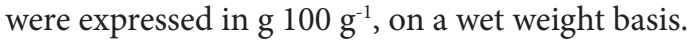

\subsection{Total amino acid profile and trypsin inhibitor}

The samples were ground, homogenized and digested using hydrochloric acid for $22 \mathrm{~h}$ at $110{ }^{\circ} \mathrm{C}$ under vacuum in a digester block to release the amino acids from the proteins by hydrolysis, followed by derivatization in a pre-column with phenyl isothiocyanate (PITC). The phenylthiocarbamyl amino acids (PTC-aa) were separated and identified by high-performance liquid chromatography (Shimadzu Corporation, Tokyo, Japan) using a reversed phase Phenomenex-Luna C18 column (Phenimenex Inc., Torrence, CA, USA), $250 \mathrm{~mm} \times 4.6 \mathrm{~mm}$ and $5 \mu \mathrm{m}$. The mobile phase consisted of an acetate buffer

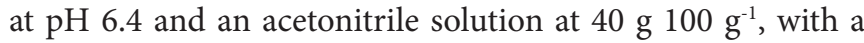
constant flow rate of $1 \mathrm{~mL} \mathrm{~min}{ }^{-1}$ at $35^{\circ} \mathrm{C}$. Sample injection was automatic $(50 \mu \mathrm{L})$ and detection was at $254 \mathrm{~nm}$. The run time was $45 \mathrm{~min}$ and the results were expressed in $\mathrm{mg} 100 \mathrm{~g}^{-1}$. The amino acids were identified by comparison with an external standard (Pierce, PN 20088), and quantified using an internal standard 
of $a$-aminobutyric acid (Sigma-Akdrich, St. Louis, MO, USA) according to Hagen et al. (1989).

The trypsin inhibitor activity was quantified based on the hydrolysis of the ester bond and amide of benzoyl-L-arginine p-nitroanilide (Bapa), releasing a synthetic derivative of these amino acids due to the action of free trypsin. In the presence of trypsin inhibitor in the sample, this would inhibit the action of trypsin on the Bapa. During the hydrolysis of Bapa by trypsin, p-nitroanilide was released, which was measured in a spectrophotometer at $410 \mathrm{~nm}$ (Rackis et al., 1974).

\subsection{Microbiological risk, sensory acceptance and purchase intent}

The samples were evaluated according to the methods established by the American Public Health Association (2012). Coliforms at $45^{\circ} \mathrm{C}$, coagulase-positive Staphylococci and Salmonella sp. were evaluated after 10 days of incubation at $35-37^{\circ} \mathrm{C}$, and after 5 days of incubation at $55^{\circ} \mathrm{C}$, according to the Brazilian Health Regulatory Agency (Brasil, 2001).

The sample was served in transparent plastic under white light. To evaluate acceptance of the flavor, texture and appearance of the soybean preserve, a nine point hedonic scale was used, with the extreme terms of "like extremely" and "dislike extremely". A 5-point scale was used for purchase intent $(1=$ definitely not buy, $3=$ maybe buy/maybe not buy and 5 = definitely buy) (Stone et al., 2012). The level of acceptance was previously established as a mean score higher than five (neither liked nor disliked) for all attributes, according to Associação Brasileira de Normas Técnicas (1998). The panel was composed of 53 people with an age range of 20-40 (Ethics Committee protocol number 041/13).

\subsection{Analysis of the results}

The data were evaluated by an analysis of variance and multiple regressions using Statistica 7.0 (Statsoft, Statistica 7.0, Tulsa, USA). The Response Desirability Profiling function was used to estimate the most desirable soybean preserve.

\section{Results and discussion}

\subsection{Effect of maceration time and acetic acid content on physical and chemical characteristics of the soybean preserves}

The models calculated from the data obtained for the soybean preserves as a function of the maceration time and the acetic acid concentration in the brine were significant $(\mathrm{p} \leq 0.05)$ for moisture and hardness, which correspond to 71 and $80 \%$ of the responses. The total phenolic compound contents of the grains and the solids losses to brine of preserves were significant $(\mathrm{p} \leq 0.10)$, which correspond to 51 and $68 \%$ of the responses. The lack of fit of the models was not significant ( $L F>0.05$ ), except for the instrumental hardness model (Table 1). However, according to Waszczynskyj et al. (1981), when the mean square for the experimental error presents a low value $(<5 \%)$, the significance tests for lack of fit must be deemed irrelevant.

The moisture content varied $6.7 \%$, between 59.9 and

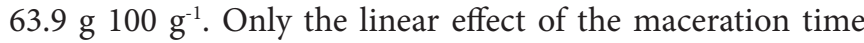
$(\mathrm{p}<0.05)$ and the linear $(\mathrm{p}<0.05)$ and quadratic $(\mathrm{p}<0.10)$ effects of the acetic acid concentration influenced the moisture content of the soybean preserves (Table 1). The moisture content was higher for higher maceration times and lower acetic acid concentrations (Figure 1A). In the presence of acetic acid, cell wall undergo structural modifications, which facilitates the reduction in water absorption capacity by the product (Zhao et al., 2017).

The hardness of the soybean preserve grains varied $83.3 \%$, between 48.04 and $88.10 \mathrm{~N}$ (Figure 1B). The maceration time (linear effect) and the acetic acid concentration in the brine (quadratic effect) influenced $(p<0.05)$ the hardness of the soybean grains (Table 1). The longer the maceration time, the lower was the hardness of the grains, while an increase inacetic acid concentration in the brine initially increased and then decreased grain hardness (Figure 1B).

The lowest values for hardness $(<70 \mathrm{~N})$ were obtained with a maceration time longer than $50 \mathrm{~min}$ and acetic acid

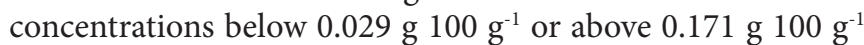
(quadratic effect). The reduction in hardness of the grains is due to the water content absorbed by the leguminous grain in the maceration process, which reduces the resistance of the grain (Pan \& Tangratanavalee, 2003). On the other hand, acetic acid increases grain hardness. Zhao et al. (2017) found that the influence of acetic acid on potato hardness was due to structural changes in the cell wall polysaccharides due to dissolution or biochemical changes, resulting in more branching of the cell wall polysaccharides, which strengthens the bonds between the polysaccharides.

It was shown that the maceration time reduced the losses of total phenolic compound in the preserve with no added acetic acid, whereas high acetic acid contents produced the opposite effect (interaction effect), with an increase in maceration time increasing the losses of the total phenolic compound content (linear effect) (Figure 1C). Phenolic compounds are known

Table 1. Multiple regression models and determination coefficients for hardness (N), total phenolic compounds (TPC) (mg GAE $\left.100 \mathrm{~g}^{-1}\right)$, solids

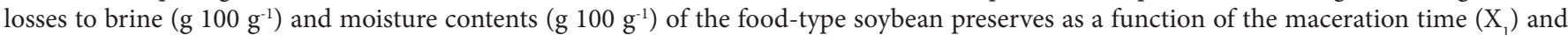
acetic acid concentration $\left(\mathrm{X}_{2}\right)$ in encoded values.

\begin{tabular}{lccc}
\hline \multicolumn{1}{c}{ Characteristic } & Model & $\mathrm{R}^{2}$ & Lack of fit \\
\hline Hardness & $\mathrm{y}=78.14-9.0 \mathrm{x}_{1}^{*}-8.08 \mathrm{x}_{2}^{2 *}$ & 0.71 & 0.01 \\
TPC & $\mathrm{y}=123.95-2.78 \mathrm{x}_{1}^{* *}-4.26 \mathrm{x}_{1} \mathrm{x}_{2}^{* *}$ & 0.51 & 0.74 \\
Solidslosses & $\mathrm{y}=2.82+0.194 \mathrm{x}_{1}^{* *}-0.286 \mathrm{x}_{1}^{2 * *}+0.30 \mathrm{x}_{1} \mathrm{x}_{2}^{* *}$ & 0.68 & 0.82 \\
Moisture & $\mathrm{y}=61.37+1.49 \mathrm{x}_{1}^{*}-1.51 \mathrm{x}_{2}^{*}+1.51 \mathrm{x}_{2}^{2 *}$ & 0.80 & 0.37 \\
\hline
\end{tabular}

${ }^{*} \mathrm{p} \leq 0.05 ;{ }^{* *} \mathrm{p} \leq 0.01$. 
(A)

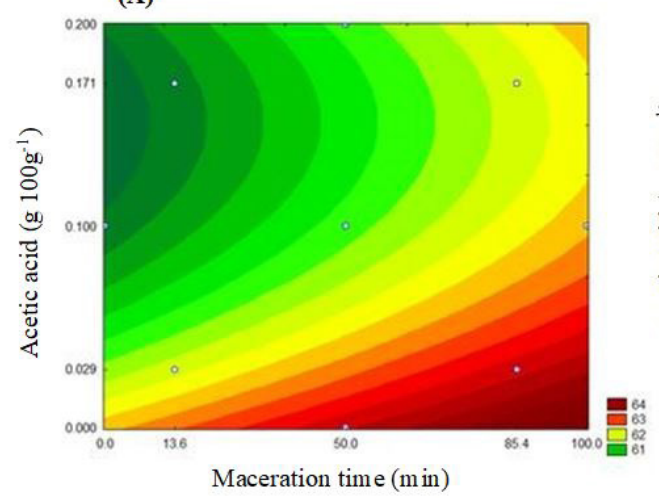

(C)

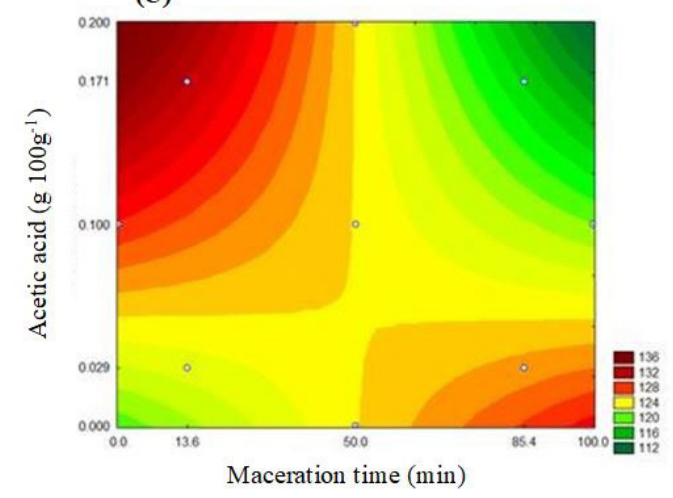

(B)

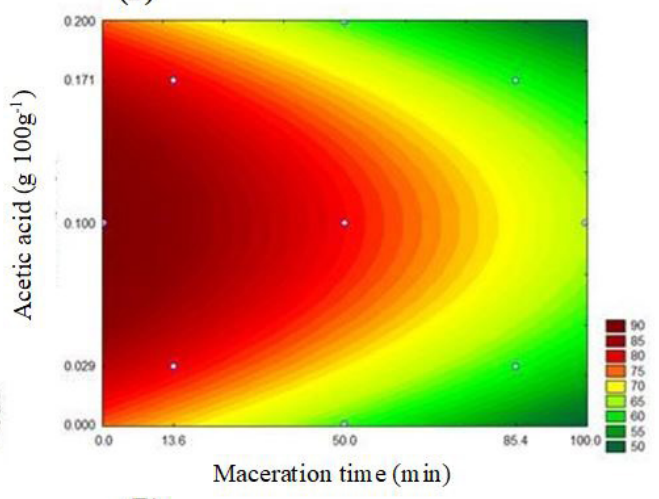

(D)

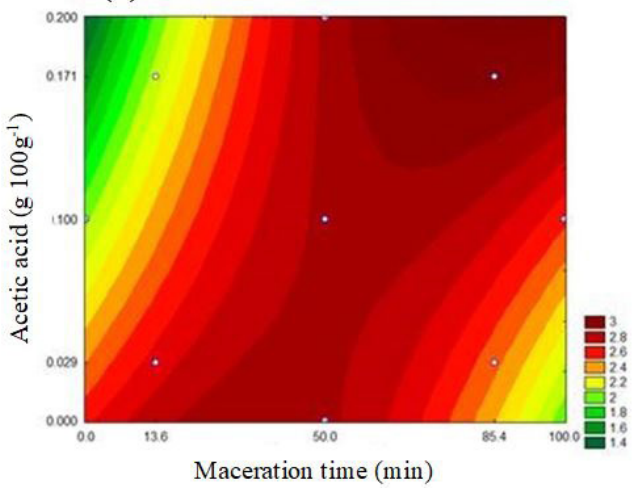

Figure 1. (A) Moisture (g $100 \mathrm{~g}^{-1}$ ); (B) Hardness (N); (C) Total phenolic compounds (mg Eq. gallic ácid g-1); and (D) Solids losses to brine (\%) from soybean preserves (Glycine max (L.) Merrill, BRSMG 790A cultivar), a function of the maceration time (min) and acetic acid concentration $\left(\mathrm{g} 100 \mathrm{~g}^{-1}\right)$.

to have essential medicinal and antioxidant properties, and contribute to the physiological activity of various medicinal plants (Rajan et al., 2010). The maceration process contributes to a reduction in the total phenolic compounds, since some of these compounds leach into the maceration solvent due to the fact that they are water-soluble compounds, which facilitates their extraction into the maceration water (Bayram et al., 2004). In addition, the heat treatment contributes to an increased loss of phenolic compounds by leaching of the hydrophilic phenolic compounds, thus degrading the polyphenols, transforming the phenolic compounds and stimulating additional chemical reactions (Kim et al., 2015). When the maceration time was short, an increase in acetic acid concentration facilitated the loss of total phenolic compounds from the grains into the preserve solution, but when it was long the loss of TPCs was low.

Acetic acid treatment affected the isoflavone and carbohydrate compositions and contents during the production of pickled soybeans (Kim et al., 2015). Such alterations may have been the cause of the increase in phenolic compounds in the preserve subjected to a short maceration time. On the other hand, alterations in the composition of the phenolic compounds can contribute to a greater loss of these compounds to the brine when subjected to a longer maceration time.

The solids losses from soybean to brine preserves varied

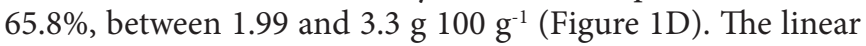
and quadratic effects of the maceration time $(p<0.1)$ and the interaction effect (maceration time and acetic acid concentration) influenced the solids loss from soybean to brine preserves (Table 1).

It was verified that for up to $50 \mathrm{~min}$ of maceration, the longer the time, the higher the solids concentration in the water (Figure 1D). The lowest value obtained for solids losses was found in the interval between 0 and $14 \mathrm{~min}\left(1.99 \mathrm{~g} 100 \mathrm{~g}^{-1}\right)$ and acetic

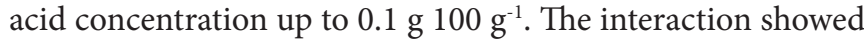
a negative effect causing higher solids losses from the soybean preserve in the time interval between 0 and $85 \mathrm{~min}$.

Increases in the maceration time and acetic acid concentration resulted in higher solids losses to the brine of the preserve. Also, due to the osmotic gradient, as with the total phenolic compounds, this occurred with the other water-soluble substances in the tissues, such as sugars, minerals and vitamins (Lestinne et al., 2005).

The presence of the acid accelerates biochemical reactions in the soybean, which facilitates the loss of compounds to the brine, resulting in an increase in solids loss. Kim et al. (2015) found that the polysaccharide content of the brine increased with time due to biochemical reactions triggered by the presence of acetic acid.

For the desirability analysis, the aim was to produce a less hard $(\mathrm{N})$ sample with solids loss from soybean to brine preserves, and higher total phenolic compounds and moisture contents in the grains. This condition was obtained with a maceration time of $100 \mathrm{~min}(+1.41)$ and $0 \%$ of acetic acid concentration 
$(-1.41)$. Although acetic acid is an excellent preservative and was chosen according to its sensory characteristics in order for the product to be consumed as an appetizer, its presence in the brine was detrimental to the quality of the soybean preserves, as opposed to the maceration time, where increases raised the moisture content and reduced grain hardness.

\subsection{Characterization of the optimized soybean using the desirability test}

The moisture, ash and protein contents found in the raw soybean (Table 2) approached the values found by Benassi et al. (2011), which for the same cultivar, but grown and harvested in the Triângulo Mineiro (BRSMG 790A cultivar), reported a moisture

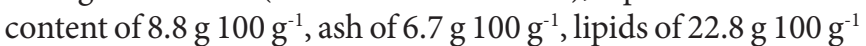

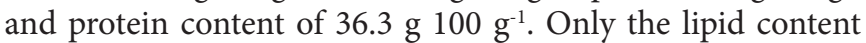
obtained in the present study was lower, by $46.6 \%$.

Commercial products such as the cooked soybean (brand 1), consisting of water, soybean and salt, reported values of $7.7 \mathrm{~g}$ of carbohydrate, $13.0 \mathrm{~g}$ of protein and $6.7 \mathrm{~g}$ of total fat per $75.0 \mathrm{~g}$ portion on the package label, while the soybean in preserve (brand 2), consisting of soybean, water, salt and sugar, showed values of $9.0 \mathrm{~g}$ of carbohydrate, $11.0 \mathrm{~g}$ of protein and $6.0 \mathrm{~g}$ of

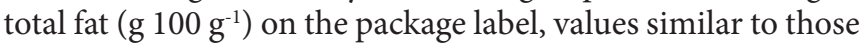
obtained in the selected experimental preserve.

The soybean preserve presented a moisture content that was $84.5 \%$ higher than the dry grains (Table 2). The high moisture content of the preserve was due to the stages of maceration and cooking, during which the grains absorbed water. Silva et al. (2013)

Table 2. Moisture, ash, protein, lipid and carbohydrate contents of the dry grains and optimized food-type soybean preserve (Glycine max (L.) Merrill, BRSMG 790A cultivar) (mean values followed by the standard deviation and variation coefficient).

\begin{tabular}{lcc}
\hline \multicolumn{1}{c}{ Parameter } & Dry grain & Soybean preserve \\
\hline Moisture $^{1}$ & $9.45 \pm 0.06(0.69)$ & $61.1 \pm 0.5(0.84)$ \\
Ash $^{1}$ & $6.15 \pm 0.09(1.49)$ & $4.46 \pm 0.09(2.00)$ \\
Lipid $^{1}$ & $15.4 \pm 0.1(0.85)$ & $6.89 \pm 0.03(0.39)$ \\
Protein $^{1}$ & $33.4 \pm 0.8(2.36)$ & $15.1 \pm 0.3(1.84)$ \\
Carbohydrate $^{1}$ & 35.61 & 12.5 \\
\hline
\end{tabular}

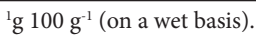

evaluated the proximal composition of raw and cooked beans and found the moisture value of the cooked grain to be 5 times greater than that of the dry grains (raw). Different levels of moisture, ashes, lipids, protein and carbohydrates were observed between the dry grain and the ready-to-eat food. This difference was related to interaction between grain and brine undergone during heat treatment in the preparation of preserve (Pedrosa et al., 2015).

The in nature grain and the soybean preserve showed higher values for all essential amino acids when compared to the standard value suggested for healthy children and adults by the Food and Nutrition Board (2005). In short, the amino acid composition of the in nature grain and the optimized soybean preserve met the amino acids standard proposed for children of one year and above, as recommended by the Food and Nutrition Board (2005) (Table 3).

The amino acids found in greatest abundance in the dry soybean and in the preserve were the non-essential amino acids (glutamic acid followed by aspartic acid), all showing higher levels in the preserve (Table 4). The values found for the total, essential, conditionally essential and non-essential amino acids varied positively $13.5 \%, 17.2 \%, 5.0 \%$ and $10.8 \%$, respectively, for the preserve in relation to the dry grains.

Considering the standard values proposed for the total essential amino acids for children and adults, the values were $69.4 \%$ and $85.8 \%$ higher than the proposed values, respectively. The total essential amino acid content increased in the soybean preserve after cooking. There was a reduction of the protein content in the thermally treated soybean (Table 2), altering the relative concentration of amino acids. A similar result was observed in soybeans cooked with rice (Kim et al., 2015).

The antioxidant activity of the raw grain $(26.77 \pm 1.82 \%)$ was 3.2 times higher than in the processed preserve $(8.36 \pm 0.78 \%)$, so the preserve retained approximately $31.25 \%$ of the antioxidant activity. The antioxidant capacity of the grain can be reduced or increased depending on the processing method used (Pedrosa et al., 2015), since thermal processing contributes to the degradation of antioxidant compounds.

The trypsin inhibitor was present in the soybean dry grains (14.6 UIT $\mathrm{mg}^{-1} \pm 86.26$ ), but was not found in the soybean preserve (zero); thus the processing of the preserve inactivated the trypsin inhibitor. These substances may interfere with protein

Table 3. Essential amino acid contents of the dry soybean and optimized soybean preserve in mg amino acid per g protein and the standard amino acid values proposed for infants, preschool children and adults based on the needs estimated for protein and essential amino acids.

\begin{tabular}{|c|c|c|c|c|c|c|c|c|}
\hline & Leucine & Lysine & Phenols+Tyrosine & Valine & Isoleucine & Threonine & Methyl+Cysteine & $\mathrm{TEAA}^{\mathrm{c}}$ \\
\hline Dry grain & $73.23 \pm 0.03$ & $61.25 \pm 0.05$ & $82.32 \pm 0.03$ & $48.5 \pm 0.1$ & $43.52 \pm 0.09$ & $40.19 \pm 0.01$ & $29.83 \pm 0.07$ & 378.81 \\
\hline Soybean preserve & $84.52 \pm 0.05$ & $68.0 \pm 0.1$ & $97.9 \pm 0.2$ & $55.2 \pm 0.2$ & $50.21 \pm 0.07$ & $47.58 \pm 0.02$ & $40.6 \pm 0.1$ & 444.00 \\
\hline Range \% & 13.3 & 9.9 & 15.9 & 12.2 & 13.3 & 15.5 & 26.4 & 14.7 \\
\hline \multicolumn{9}{|l|}{ Standard ${ }^{1}$} \\
\hline Infants $^{\mathrm{a}}$ & 101 & 69 & 87 & 56 & 57 & 47 & 38 & 455 \\
\hline 1 to 3 years $^{\mathrm{b}}$ & 55 & 51 & 47 & 32 & 25 & 27 & 25 & 262 \\
\hline$>18$ years $^{\mathrm{b}}$ & 52 & 47 & 41 & 29 & 23 & 24 & 23 & 239 \\
\hline
\end{tabular}

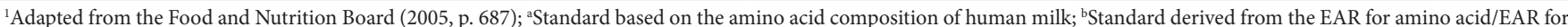
protein; for the 1 to 3 year old group: protein $\mathrm{EAR}=0.88 \mathrm{~g} \mathrm{~kg}^{-1}$ day and for adults: protein $\mathrm{EAR}=0.66 \mathrm{~g} \mathrm{~kg}^{-1}$ day. EAR is the estimated average requirement; ${ }^{\mathrm{C}} \mathrm{TEAA}=$ total essential amino acids. 
Table 4. Conditionally essential, non-essential and total amino acids of the fresh soybean and the optimized preserve in $\mathrm{mg}$ amino acid $\mathrm{g}^{-1}$ protein.

\begin{tabular}{|c|c|c|}
\hline Parameter & Dry grain & Preserve \\
\hline \multicolumn{3}{|c|}{ Conditionally essential amino acids } \\
\hline Tyrosine & $32.57 \pm 0.03$ & $41.6 \pm 0.2$ \\
\hline Cysteine & $16.18 \pm 0.09$ & $23.13 \pm 0.07$ \\
\hline Arginine & $82.57 \pm 0.05$ & $91.19 \pm 0.02$ \\
\hline Glycine & $41.6 \pm 0.1$ & $23.13 \pm 0.07$ \\
\hline Proline & $47.6 \pm 0.1$ & $52.6 \pm 0.1$ \\
\hline \multicolumn{3}{|c|}{ Non-essential amino acids } \\
\hline Glutamicacid & $184.36 \pm 0.01$ & $205.89 \pm 0.02$ \\
\hline Asparticacid & $117.90 \pm 0.04$ & $129.24 \pm 0.04$ \\
\hline Serine & $51.06 \pm 0.06$ & $58.74 \pm 0.03$ \\
\hline Alanine & $43.6 \pm 0.1$ & $46.4 \pm 0.1$ \\
\hline $\mathrm{TAA}^{\mathrm{a}}$ & 973.34 & $1,104.59$ \\
\hline TCEAA $^{\mathrm{b}}$ & 220.47 & 231.56 \\
\hline TNEAA $^{c}$ & 396.96 & 440.31 \\
\hline
\end{tabular}

digestion and cause pancreatic disorders, however, they are easily destroyed by heat (Li et al., 2017). Martinez et al. (2011) found higher values in relation to the values found in this study, with 181.93 (UIT $\mathrm{mg}^{-1}$ ) soybean before germination $(6.71 \%$ of moisture content) and 169.98 (UIT $\mathrm{mg}^{-1}$ ) after germination

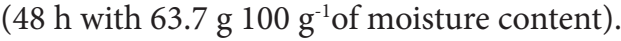

\subsection{Microbiological risk, consumer acceptance and purchase intent}

The microbiological counts of the soybean preserve were below the maximum limits established by Brazilian law: Thermo tolerant Coliforms $\left(10^{2} \mathrm{CFU} \mathrm{g}^{-1}\right)$, coagulase positive Staphylococci $\left(5 \times 10^{2} \mathrm{CFU} \mathrm{g}^{-1}\right)$ and Salmonella sp (absence in $\left.25 \mathrm{~g}\right)$. Furthermore, the results obtained for the three microorganisms evaluated in the food-type preserve, did not change after 10 days of incubation at $35-37^{\circ} \mathrm{C}$ or after five days of incubation at $55^{\circ} \mathrm{C}$. The results suggest that the soybean preserve produced was a microbiologically safe product, reinforcing the hypothesis that good raw materials and proper handling methods were used.

The average scores and standard deviations obtained for the optimized soybean preserve were $7.1 \pm 1.4$ for appearance (liked moderately). Considering the following attributes: texture, taste and flavor, the scores were between 5 (neither liked nor disliked) and 6 (liked slightly), above the pre-set level 5 (neither liked nor disliked) for acceptance of the soybean preserve. This modest acceptance of the product can probably be explained by the lack of a consumption habit for soybean preserve. One of the factors for the low consumption of soybean products is due to the fact that the consumers have little access to information on the nutritional quality of the soybean or to its beneficial effects on health (Bedani et al., 2007). The scores for purchase intent ranged between 3 (maybe buy / maybe not buy) and 4 (possibly buy). The tasters also reported a lack of consumption of soybean preserve, which might have negatively affected the results.

\section{Conclusions}

The presence of acetic acid in the brine was prejudicial to the quality of the soybean preserve BRSMG 790A cultivar. The soybean preserve with the best characteristics was obtained with a maceration time of 100 minutes and without the addition of acetic acid. The product was microbiological safe, free of trypsin inhibitor, showed sensory acceptance and had a high nutritional value, mainly for protein and lipid. The essential amino acids represented $17.2 \%$ of those in the dry grain, more than $50 \%$ the standard values proposed for the essential amino acids for children and adults. The selected preserve maintained $31.25 \%$ of the antioxidant activity of the dry grains and could be used as a viable technological option.

\section{Acknowledgements}

The authors are grateful for the financial support from CAPES - Coordination for the Improvement of Higher Education Personnel.

\section{References}

American Public Health Association - APHA. (2012). Standard methods for the examination of water and wastewater (22nd ed.). Washington: APHA.

Associação Brasileira de Normas Técnicas - ABNT. (1998). NBR 14141: escalas utilizadas em análise sensorial de alimentos e bebidas. Rio de Janeiro: ABNT.

Association of Official Analytical Chemists - AOAC. (2012). Official methods of analysis of the AOAC International (19th ed.). Washington: AOAC.

Bayram, M., Kaya, A., \& Oner, M. D. (2004). Changes in properties of soaking water during production of soy-bulgur. Journal of Food Engineering, 61(2), 221-230. http://dx.doi.org/10.1016/S02608774(03)00094-3

Bedani, R., Miguel, D. P., Chaves, I. R., Jung, E. B., Oliveira, P. F., Guaglianoni, D. G., \& Rossi, E. A. (2007). Consumo de soja e seus produtos derivados na cidade de Araraquara - SP: um estudo de caso. Alimentos e Nutrição, 18(1), 27-34.

Benassi, V. T., Benassi, M. T., \& Prudêncio, S. H. (2011). Cultivares brasileiras de soja: características para a produção de tofu e aceitação pelo mercado consumidor. Semina: Ciências Agrárias, 32(1), 19011914. http://dx.doi.org/10.5433/1679-0359.2011v32n4Sup1p1901.

Box, G. E. P., Hunter, W. G., \& Hunter, J. S. (2005). Statistics for experimenters: design, innovation, and discovery (2nd ed). New York: John Wiley.

Boz, Z., \& Erdogdu, F. (2015). Thermal processing: canning and aseptic processing. In Y. H. Hui \& E. Ozgul-Evranuz (Eds.), Handbook of vegetable preservation and processing (pp. 157-174). New York: CRC Press. http://dx.doi.org/10.1201/b19252-10.

Brasil. Agência Nacional de Vigilância Sanitária - ANVISA. (2001, January 10). Aprova o Regulamento Técnico sobre padrões microbiológicos para alimentos (Resolução RDC no 12, de 2 de janeiro de 2001). Diário Oficial [da] República Federativa do Brasil. Retrieved from http://portal.anvisa.gov.br/legislacao\#/visualizar/26655

Czaikoski, K., Leite, R. S., Mandarino, J. M. G., Carrão-Panizzi, M. C., Silva, J. B., \& Ida, E. I. (2013). Canning of vegetable-type soybean in acidified brine: effect of the addition of sucrose and pasteurization 
time on color and other characteristics. Industrial Crops and Products, 45(1), 472-476. http://dx.doi.org/10.1016/j.indcrop.2012.09.009.

Food and Nutrition Board - FNB. (2005). Dietary references intakes for energy, carbohydrate, fiber, fat, fatty acids, cholesterol, protein, and amino acids (macronutrients). Washington: The National Academies Press. Retrieved from http://www.nap.edu/openbook. php?isbn=0309085373

Hagen, S. R., Frost, B., \& Augustin, J. (1989). Precolumn phenylisothiocyanate derivatization and liquid chromatography of amino acids in food. Journal of the Association of Official Analytical Chemists, 72(6), 912-916. PMid:2592313.

Hung, P. V., Maeda, T., Miyatake, K., \& Morita, N. (2009). Total phenolic compounds and antioxidant capacity of wheat graded flours by polishing method. Food Research International, 42(1), 185-190. http://dx.doi.org/10.1016/j.foodres.2008.10.005.

Khattab, R. Y., \& Arntfield, S. D. (2009). Nutritional quality of legume seeds as affected by some physical treatments 2: antinutritional factors. Lebensmittel-Wissenschaft + Technologie, 42(2), 1113-1118. http://dx.doi.org/10.1016/j.lwt.2009.02.004.

Kim, S. H., Yu, B. R., \& Chung, I. M. (2015). Changes in the contents and profiles of selected phenolics, soyasapogenols, tocopherols, and amino acids during soybean-rice mixture cooking: electric rice cooker vs electric pressure rice cooker. Food Chemistry, 176, 45-53. http://dx.doi.org/10.1016/j.foodchem.2014.12.024. PMid:25624205.

Lestinne, I., Mouquet-River, C., Icard-Vernière, C., Rochette, I., \& Trèche, S. (2005). The effects of soaking of whole, dehulled and ground millet and soybean seeds on phytate degradation an Phy:Fe and Phy:Zn molar ratios. International Journal of Food Science \& Technology, 40(7), 391-399. http://dx.doi.org/10.1111/j.1365-2621.2004.00941.X.

Li, J., Xiang, Q., Liu, X., Ding, T., Zhang, X., Zhai, Y., \& Bai, Y. (2017). Inactivation of soybean trypsin inhibitor by dielectric-barrier discharge (DBD) plasma. Food Chemistry, 232(2), 515-522. http:// dx.doi.org/10.1016/j.foodchem.2017.03.167. PMid:28490106.

Martinez, A. P. C., Martinez, P. C. C., Souza, M. C., \& Brazaca, S. G. C. (2011). Chemical change in soybean grains with germination. Food Science and Technology, 31(1), 23-30. http://dx.doi.org/10.1590/ S0101-20612011000100004.

NIIR Board of Consultants \& Engineers. (2016). The complete technology book on processing, dehydration, canning, preservation of fruits \& vegetables (3rd ed). Delhi: NIIR Project Consultancy Services.

Pan, Z., \& Tangratanavalee, W. (2003). Characteristics of soybeans as affected by soaking conditions. Lebensmittel-Wissenschaft + Technologie, 36(1), 143-151. http://dx.doi.org/10.1016/S0023-6438(02)00202-5.
Pedrosa, M. M., Cuadrado, C., Burbano, C., Muzquiz, M., Cabellos, B., Olmedilla-Alonso, B., \& Asensio-Vegas, C. (2015). Effects of industrial canning on the proximate composition, bioactive compounds contents and nutritional profile of two Spanish common dry beans (Phaseolus vulgaris L.). Food Chemistry, 166, 68-75. http://dx.doi. org/10.1016/j.foodchem.2014.05.158. PMid:25053030.

Price, M. L., Van Scoyoc, S., \& Butler, L. G. (1978). A critical evaluation of the vanillin reaction as an assay for tannin in sorghum grain. Journal of Agricultural and Food Chemistry, 26(5), 1214-1218. http:// dx.doi.org/10.1021/jf60219a031.

Rackis, J. J., Mc Ghee, J. E., Kakade, M. L., \& Puski, G. (1974). Problems encountered inmeasuring trypsin inhibitor activity of soy flour: report of a collaborative analysis. Cereal Science Today, 19, 513-515.

Rajan, S., Gokila, M., Jency, P., Brindha, P., \& Sujatha, R. K. (2010). Antioxidant and phytochemical properties of Aegle marmelos fruit pulp. International Journal of Current Pharmaceutical Research, $3(2), 65-70$

Sanjukta, S., \& Rai, A. K. (2016). Production of bioactive peptides during soybean fermentation and their potential health benefits. Trends in Food Science \& Technology, 50, 1-10. http://dx.doi.org/10.1016/j. tifs.2016.01.010.

Silva, M. O., Brigide, P., \& Canniatti-Brazaca, S. G. (2013). Composition of common bean cultivars. Brazilian Journal Food Nutrition, 24, 339-346.

Singleton, V. L., Orthofer, R., \& Lamuela-Raventos, R. M. (1999). Analysis of totalphenols and others oxidation substrates and antioxidants by means of Folin-Ciocaulteau reagent. Methods in Enzymology, 299, 152-178. http://dx.doi.org/10.1016/S0076-6879(99)99017-1.

Stone, H., Bleibaum, R., \& Thormas, H. (2012). Sensory evaluation practices (4th ed.). New York: Academic Press.

Thaipong, K., Boonprakob, U., Crosby, K., Cisneros-Zevallos, L., \& Byrne, D. H. (2006). Comparison of ABTS, DPPH, FRAP, and ORAC assays for estimating antioxidant activity from guava fruit extracts. Journal of Food Composition and Analysis, 19(6-7), 669-675. http:// dx.doi.org/10.1016/j.jfca.2006.01.003.

Waszczynskyj, N., Rao, C. S., \& Silva, R. S. F. (1981). Extraction of proteins from wheat bran: application of carbohydrases. Cereal Chemistry, 58, 264-266.

Zhao, W., Shehzad, H., Yan, S., Li, J., \& Wang, Q. (2017). Acetic acid pretreatment improves the hardness of cooked potato slices. Food Chemistry, 228(8), 204-210. http://dx.doi.org/10.1016/j. foodchem.2017.01.156. PMid:28317714. 